\title{
DEVELOPMENT OF LIFE SKILLS EDUCATION AS CHARACTER BUILDING
}

\author{
Fajar Defitrika ${ }^{*}$, Fitri Nur Mahmudah² \\ 1,2 Department of Education Management, Universitas Ahmad Dahlan, Yogyakarta, \\ Indonesia \\ *fajar.fd1272@gmail.com
}

\begin{tabular}{l}
\hline \hline Article Info \\
\hline Article history \\
Received: December 9, 2020 \\
Revised: December 28, 2020 \\
Accepted: January 1, 2021 \\
\hline
\end{tabular}

\section{Keywords:}

Character education;

Life skills:

Strategy.

\begin{abstract}
The industrial era 4.0 requires that every individual must have superior competence and wise morals. Life skill education is an effective strategy to face the XXI century competition. However, there has been no development in line with the demands, resulting in much unemployment in Indonesia. Character education is encouraged to maintain and strengthen the culture and character of the nation. However, in reality, character education has not yet integrated into all school-based development programs. This research explores the development of character education based on life skill education at Pondok Pesantren Modern Muhammadiyah Boarding School (PPM MBS) Yogyakarta. This qualitative research uses an ethnographic approach. Researchers' data is through the interview, observation, and documentation techniques-data analysis process with data reduction stages, data presentation, and conclusion. Triangulation sources and techniques used as a test of data validity. This study's findings show the strengthening of character education through life skills education orienting on self-development and boarding schools' cultural development. This study's findings recommend various life skill education programs that can develop and character education strategies in formal schools.
\end{abstract}

\section{INTRODUCTION}

Character education increasingly highlighted by the enactment (Peraturan Menteri Pendidikan dan Kebudayaan RI Nomor 20 Tahun 2018 Tentang Penguatan Pendidikan Karakter Pada Satuan Pendidikan Formal, 2018; Peraturan Presiden RI Nomor 87 Tahun 2017 Tentang Penguatan Pendidikan Karakter, 2017). The focus point of education is not only on the cognitive realm but also on the citizens' character (civic disposition). The emphasis on character education has long been with the existence of "nation-building and character" (Nugroho, 2008). The character education process strategically integrated into the education system components, curriculum, teaching and learning activities, extracurricular activities, and school culture. Formal schools are considered useful in fostering and strengthening children's character; they limited by time allocation. Students in the school environment range from 7-8 hours a day, resting in the family and community environment. It is necessary to increase the allocation of more or more time in school (Nucci et al., 2014). It should note that if a child is in a lousy environment, it will cause moral degradation (Handono et al., 2019; Schofield et al., 
2015; Sohn et al., 2019). Environmental studies affect student character. There is a relationship between the two (Hasbullah, 2012). Moreover, Utami et al. (2016) reveal that the family environment has a central task in children's education which acts as the necessary foundation of education. The child's perspective on life comes from parents and the surrounding community.

Comparative data on the Human Development Index (HDI) issued by the UNDP (2018), Indonesia noted that in 2018 this had decreased by one rank in rank 116 with a value of 0.694 . It is because education in Indonesia still does not provide life skills. Human Development Indicators have three basic dimensions of human development, first, length and heat, second, life skills, and finally, a decent standard of living (Anwar, 2015). The education system in Indonesia needs to optimize the educational process oriented towards life skills education, including life skills programs for students. Furthermore, Anwar (2015) explains that the preparation of resources is the primary key in competition in the era of globalization. Life skills education is a form of investment in the future, achievement in living life, and competition. Woodhall who wrote Human Capital Concepts in 1987 revealed that humans who progress through education, training, and other activities that are in line with their way of life, in the future in economic theory is called "investment" (Suhardan, 2012). Suhardan (2012) adds that students with high life skills are national assets, human capital, problem solvers for national development, human investment.

Advances in technology, information, communication trigger disruption. Adolescents who can take advantage of these developments make a useful contribution. On the other hand, they can cause deviant behaviour if they are not used properly (Tomczyk, 2017). Based on the Indonesian Child Protection Commission (KPAl, 2017, 2018) data bank, it recorded that from 2011 to 2016 there was an increase in the amount of moral degradation in various cases, pornography, cybercrime, trafficking, exploitation, bullying, drug users, and dealers.

The full-day school system requires an additional allocation of time each day but five school days a week. So it is necessary to have full-day school control, in the form of internal and external monitoring, collaboration with parents of students (Iskandar \& Narimo, 2017), research by Leasa and Batlolona (2017) shows the effectiveness of program learning. Another alternative, optimizing education management in schools, requires systematic planning, organization, implementation, and supervision (Julistiaty et al., 2018). In a broader range, the education system needs to change the direction of education, the foundation of the educational process refers to the concept of learning not being taught (Rokhman et al., 2014; Saidek et al., 2016).

The character of students are also part of life skills education, where on the other hand students must have good character in life skills. Therefore, it is necessary to look directly at how the character education process oriented towards life skills education. It becomes a reference 
in decision making in the development of life skills education and strengthening character education.

\section{METHOD}

This research uses qualitative methods with an ethnographic approach. The research was conducted at the Modern Muhammadiyah Boarding School (PPM MBS) Islamic Boarding School in Yogyakarta. Determination of location based on pre-research research. The study's length was 17 months starting from 2018 to 2020, intensively for the remaining two months as ethnographic monitoring. The research subjects were Deputy Director I of the Muhammadiyah Islamic Boarding School (MBS) Yogyakarta in the field of education, general treasurer, junior and senior high school principals, male and female boarding heads, male and female dormitory coaches, head of the general curriculum and pesantren, head of the male student section. The research object is the character education process in the life skills education program at PPM MBS Yogyakarta.

Data collection using interview, observation, and documentation. The outline of the problem guides the interview technique-observation technique, using moderate observation. Documentation techniques, compile and analyze documents. Data validity, through triangulation of sources and techniques, was carried out by various respondents' data credibility. Technical triangulation, testing the credibility of data by comparing data based on techniques and data.

The data analysis technique used by the researchers used the Miles and Huberman analysis model, namely data reduction, data presentation, and conclusion/verification (Miles et al., 2014). Data reduction, combining data related to life skills education in groups of students in dormitories and schools through sorting and grouping in tables to make a more real and clear picture. Data display, looking at the reduction's results, looks for the relationship pattern of education, life skills, students in the dormitories and schools outlined in the form of narrative text. Making conclusions or verification, concluding research questions, and how the character education process leads to life skills education. Data analysis carried out during the research process.

\section{RESULTS}

PPM MBS Yogyakarta is a charity business organization of the Muhammadiyah movement founded in 2008. This educational institution has a boarding school system by combining the national curriculum (2013 curriculum) with the pesantren curriculum. Various educational programs have developed.

\subsection{Daily Activity Program}

The daily activities of students in Islamic boarding schools are different from traditional schools in general. Students in traditional schools have activities in the school environment 
ranging from 7-8 hours per day. In Islamic boarding schools for 24 hours, 7-8 hours of rest time cut-the process of educational activities, starting from waking up to before bed. Routines expected to get used to discipline. Activities start at 03.30 until 22.00 WIB. Deputy director I for education (interview, May 212018 ) said that students' routine starting at 03.00 waking up, preparing to go to the mosque, praying and sahur every Monday and Thursday, morning prayers, reciting recitation, memorizing deposits, school preparation. At 07.00 hours in class until 15.00 hours. The next activities are extracurricular activities and pesantren activities, at 20.00-21.30 tutoring or studying at night together, at 22.00 students.

The head of the male and female dormitories (interview, May 18 and August 18 2018) revealed that school activity holidays fall on Friday. Students are asked to visit their parents or guardians, but only once a month to leave the boarding school area. Based on the documents that the researchers collected (documentation, the 2018 MBS PPM Yogyakarta Profile book), there is a daily activity schedule.

All students carry out these daily activities. Based on the observations of researchers (Observation, August 14-21 2018) as participant observers, researchers found patterns of students' daily activities, from waking up to 06.40 WIB, pesantren activities, from morning to noon at 15.00 WIB active in school, in the afternoon following compulsory or optional extracurricular activities. Furthermore, at night the pesantren activities will return.

\subsection{Weekly Activity Program}

There are four weekly activities for students: khitabah Asghar, ceremonies, Friday prayer and TPA (Koran education garden) teacher, Monday and Thursday sunnah fasting, compulsory or optional extracurricular activities. The research programs based on interview data with the head of the male and female dormitories, the principal of SMP SBM Yogyakarta, male or alumni boarding schools, the head of the male student department (interview, May 18, 18, 19, 21, and 21 August 2018).

The khutbah Asghar activity program develops public speaking skills. Based on the observations (observation, August 29, 2018) this activity called khutbah Asghar because the implementation of this program, students are divided into small groups with an even turnover and are more often trained. Students are required to participate in this activity. The seniors or management of the MBS Yogyakarta IPM (All Muhammadiyah Student Association) become the supervisor, companion, and person in charge of the group. The observation results corroborated by the discovery of the khutbah Asghar group division document (documentation, boarding trust sheet).

Another weekly program is a routine ceremony. Based on the opportunity, the researcher took part in a routine ceremony (observation, 22 and 29 September 2019) that routine ceremony was held on Saturdays, using three different languages alternately every week. The use of language differences in the implementation protocol; besides that, the ceremony officials also took turns-routine ceremonial activities as a forum for motivation or

IJEMI Vol.2, No.1, January 2021, pp. 116 135 
advice, awards, and announcements. The integration of character education in ceremonies instils discipline, nationalism, responsibility, and mental self-confidence and the application of national and international languages.

The weekly program is Friday preacher speaker and TPA teacher, observation (observation, August 17, 14, 21, and 28 September 2019) and document analysis (documentation, Friday Khatib Guidebook, and TPA Supervisor), this program is specifically for class students XII. The khatib presenters for male students and TPA teachers are female students in mosques around PPM MBS Yogyakarta. This program is part of the requirements for graduation.

Other character education development develops through extracurricular programs, compulsory extracurricular and optional extracurricular activities. The results of research by researchers (documentation, PPM MBS Yogyakarta Profile book 2018) and researcher observations (observations, 14-21 August and 14-29 September 2019) concluded, compulsory extracurricular activities, on Wednesday extracurricular Hizbul Wathon (scouts) and extracurricular Tapak Suci carried out Saturday. Selected extracurricular activities include sports and skills, including calligraphy, production, culinary, reading the Koran / qiro'ah, KOKAM, journalistic graphic design, football, nasyid, youth red cross (PMR), table tennis, basketball, archery, volleyball, badminton, and chess. All students must follow the extracurricular activities according to the predetermined schedule. The extracurricular options for collecting the talents and interests of students, in its implementation, follow the extracurricular participants' agreement.

In addition to the weekly programs above, the habituation program for the Sunnah fasting Monday and Thursday is also a forum for character education. This program familiarizes, instils, and strengthens the faith and worship of students. The head of the general curriculum and boarding schools, head of the male student section, interview, May 18, 20 and 21 August 2018) the Sunah fasting Monday and Thursday accustomed to deepening the religious values of students, the rest there are many benefits, including health and emotional mastery. Researchers also took observations (observation, 13, 16, August 20, 2018, and 16, 23, September 26 2019) depicting that students were more active in their emotional mastery, seen patience and gratitude, mostly there were no situations recorded that students reminded each other for emotional control.

\subsection{Monthly Activity Program}

The monthly program at PPM MBS Yogyakarta is incidental. However, routinely there are at least two program activities: internal competitions for Islamic boarding schools and khutbah Akbar. The incidental monthly program revealed the head of the male and female dormitories, the principal of the Yogyakarta MBS Junior High School, the head of the male student affairs sector (interview, May 18 and 18, 19, August 21 2018) several incidental programs that held ceremonies and competitions on independence day to commemorate 
Maulid of the prophet and global issues that need to addressed through action. It happened with discovering documentation of activities (documentation, Accountability Report of the SBM Yogyakarta IPM 2017/2018 Period).

The khutbah Akbar and khutbah Asghar programs are conceptually related to public speaking training and mental strengthening. The difference lies in the time of implementation and the participants. According to the results of observations (observation, September 1, 2019) the implementation of the grand khutbah was carried out in the yard of the dormitory or school, and the timing of the implementation adjusted to the results of the Yogyakarta MBS IPM committee meeting. Activities with all students, but separate places between male and female students.

Another monthly program that routinely implemented is the Yogyakarta MBS PPM internal competition. This activity has a concept that offers moral stimulation or the character of students to have and familiarize themselves with the mentality of competition, responsibility, cooperation, discipline, and cleanliness; this is related to the head of the female and male dormitories and the coach of the male dormitory or alumni (interview, May 18, 18 and 21) August 2018). The documentation results that corroborate information (documentation, the MBS Yogyakarta IPM Accountability Report for the 2017/2018 period) show that there are regular competitions every month in the form of room and dormitory cleaning competitions, class cleanliness, class meetings, and daily language mastery.

\subsection{Annual Activity Program}

Santri camp (santri: students in Islamic boarding schools), santri da'wah, life skills provision, santri charity (ABAS), performing arts, and santri creativity are the annual program activities PPM MBS Yogyakarta. Information on the program conveyed by the head of the male and female dormitories, male or alumni dormitory development, and the male student department (interview, May 18, 18, 21, and 21 August 2018).

The researcher looked at the ABAS program documents (documentation, the 2018 PPM MBS Yogyakarta Profile book, and the Charity Bakti Santri Guidebook). This program implemented in rural areas with 5-6 days. Students placed in residents' homes, each house contains 5-7 students to carry out social services. Every day he is required to carry out activities by the owner's daily activities so that he can explore the role of the village community in life. Also, they are required to live independently, organize religious activities, so that the realization of this program will lead to a bazaar or distribution of necessities. Indirectly, this program sharpens the sensitivity of students in life.

Another annual program is value actualization, namely the da'wah of the santri. In the month of fasting, this activity program carried out. The target of the activity is high school (senior high school) level, students. The implementation model placed in areas with little religious activity and religious teachers, interviews were given by the head of the female and male dormitories (interview, May 18 and August 18 2018). The male dormitory coach or alumni 
(interview, August 21 2018) added, dividing assignments or placements using a group system consisting of 5-6 students. Based on observations (documentation, the PPM MBS Yogyakarta Profile book 2018, and the Santri Da'wah Guide book), it is a mandatory program and implementing this activity for one week. This activity develops and actualizes knowledge with experience, mentality, and readiness to enter society.

Another annual program, namely the santri camp, completes students' compulsory activities except for class XII SMA. The implementation of male and female students carried out in different places, but the frequency of implementation is the same, namely 3-4 days. The IPM MBS Yogyakarta management determines the implementation and is responsible for the schedule. The santri camp is a form of extracurricular activity from Hizbul Wathan as a forum for students to stand up, discipline, cooperate, take responsibility, train, train leadership, and provide sensitivity to environmental and social concerns. It conveyed by the head of the female and male dormitories, male or alumni dormitory development (interview, May 18, 18 and 21 August 2018). It corroborated by examining the documents found (documentation, the 2018 MBS PPM Yogyakarta Profile book, and the MBS Yogyakarta IPM Accountability Report for the $2017 / 2018$ period).

Performing arts and creativity is an annual activity program in expressing art and challenging creativity. Deputy Director 1 for education (interview, May 21 2018) clarified by the chairman of the male and female dormitories, male or alumni boarding (interview, May 18, 18 and 21 August 2018) at these activities that have carried out and routinely carried out in the form of various performances theatre, dance, qasidah, musical poetry, martial arts. This activity also provides students with opportunities to convey, realize, and show their creativity, including skills exhibition. Interestingly, the IMP MBS Yogyakarta committee is the central committee, so they believe the event follows the management's ideas and creativity.

At the end of the school year, class XII students become busy days. They get a direct life skills program. These supplies provide soft skills and hard skills. Activities include training in leadership, culinary, hand skills (sewing/embroidery, use of used goods), training on mastery of information and communication technology (ICT), including design training, video studio, photographer, technology-based journalism. It commonly conveyed by the head of the curriculum section, the deputy director I for education, the head of the male student section (interview, 18, May 21 and 21, August 21 2018) according to the results of the researchers' observation of the documents found (documentation, the Life Skill Program Implementation book).

\subsection{Organizing Program}

This program divided into two types, first, a large-level organization within the scope of Islamic boarding schools, namely IPM MBS Yogyakarta, chairman of the boarding complex at the student/student level, second, small-scale organizing, namely mudhabir, classes, and rooms. Based on observations (observations, 14-21 August 2018 and 14-29 September 2019) 
there is structural mapping and verticalization. Researchers understand the mapping and verticalization of these structures to provide direct learning in the organization by reflecting on religious values, leadership, cooperation or cooperation, tolerance, courtesy, discipline, environmental and social care, sensitivity, and skills in summarizing global issues and solutions, which lastly provides learning to be responsible. It conveyed by the head of the female and male dormitory, the construction of the male or alumni dormitory, and the head of the student section (interview, May 18, 18, 21, and 21 August 2018). This organizing divided into several organizational structural dependencies of the learners.

This structural organization needs to underline that there is an organization between men and women. Besides, each organization has its organizational structure. MBS IPM Yogyakarta becomes IPM Men and IPM Women, and the management continues to change every period of the school year. IPM MBS Yogyakarta's role is to help organize PPM MBS Yogyakarta program activities either in dormitories or in schools. However, IPM still maintains independence as an activity by procuring programs, missions, and objectives of the IPM organization for a certain period.

SBM IPM Yogyakarta is structurally in charge of the head of the dormitory at the santri / student level, who has a role to be responsible for the problems and activities in the hostel. The mudhabir directly assists the head of the dormitory on each floor of the dormitory, which can supervise each room. Each room also has an organizational structure; the room's chairperson is directly responsible for the mudhabir related to association, tidiness, cleanliness, and discipline in rooms occupied by 12 to 16 students.

\subsection{Islamic Boarding School Cultural Actualization Program}

This program is a school and residential culture that is synergized and developed in Islamic boarding school culture. The development carried out in terms of habituation, punishment, and reward.

Habit as part of the Islamic boarding school culture requires students to correct every behaviour, bad habits for the better, 24 hours of intensive supervision and exemplary role from all parties in the boarding school environment. Exemplary as a reflective form of character habituation, providing courtesy, cleanliness, speech or language, honesty, socializing, socializing, dressing, responsibility, and discipline. The head of the female dormitory conveyed it, the deputy director I for education, the head of the male dormitory, the head of the pesantren curriculum, male or alumni dormitory development, and the head of the student section (interview, 18, May 21, 18, 20, 21, and 21 August 2018 ). Researchers' observations as participants (observation, 14-21 August 2018 and 14-29 September 2019) that teachers, dormitory coaches, and IPM MBS Yogyakarta administrators exemplify, shake hands, speak polite words, prioritize discipline, according to guidance, neat hair and clothes. The results of the observations also provide an understanding that supervision is intensive supervision. Fulltime or 24-hour supervision becomes a form of habituation strategy. The head of the female

IJEMI Vol.2, No.1, January 2021, pp. 116 135 
and male dormitory, the principal of SMP MBS Yogyakarta (interview, May 18 and 18, August 19 2018) said the same thing, supervising students was done anywhere and anytime, also accompanied by providing advice. The researcher's observations show another thing, supervision is not only carried out by teachers and dormitory supervisors, but there is also a supervisory role from the MBS Yogyakrta IPM management and the mudhabir dormitory (observation, 14-21 August 2018 and 20-29 September 2019).

Punishment and reward become a form of education life skill, merging with the Islamic boarding school's tradition or culture. Based on the results of interviews with the head of the female and male dormitory, the principal of the Yogyakarta MBS Middle School, the head of the student division (interview, May 18 and 18, 19, August 21 2018) the rewards were in the form of shopping vouchers in cooperatives, waivers of school fees and provision of daily items. Hope with the reward of students who want to achieve and continue to excel. Researchers observed (observation, 18, August 25, 2018, and 14, September 29 2019) notification and giving was a reward carried out during flag events. Delivery openly, witnessed by all students, intended to motivate students-the form of punishment intended to provide a deterrent effect, not to commit a violation. Stakeholders at the Islamic boarding school believe that a policy set is a form of education based on self-integrity to comply with applicable regulations. It conveyed by the deputy director I for education and the head of the student affairs sector (interview, May 21 and August 21 2018).

The head of the female and male dormitory, the principal of the Yogyakarta MBS Middle School (interview, May 18 and 18, August 19 2018), there are many aspects of regulations related to the continuity of life in the dormitory, namely interpersonal relationships, order to the development of students. Also, there is a categorization of types of violations; minor, moderate, and severe violations. The forms of punishment given were also relatively varied, and there was hair shaving (baldness), temporary repatriation (suspension), reading or writing of holy books (the Koran), and cleaning the boarding school environment. The exciting thing was when researchers made direct observations (observations on 14-21 August 2018 and 1429 September 2019), we found some students had bald heads, responsively the researchers conducted additional interviews, these students violated the use of language, further explained the prohibition the use of regional languages (the language of origin of students) because in PPM MBS Yogyakarta implementing three mandatory languages in interaction, namely Indonesian, Arabic, and English.

The existence of reward and punishment becomes a culture for all individuals. Life skill education and character education continue to go hand in hand with their existence at the Islamic boarding school-such educational conditions coupled with supervision and modelling into a long and complicated program.

\section{DISCUSSION}


Based on the research results, various life skill education programs that have developed show that life skills education is already running. Programs following the concept of life skills education compiled by the Ministry of National Education (Tim Broad-Based Education, 2002a, 2002b; Anwar, 2015), that life skill education refers to general life skills and specific life skills. Observe figure 1 to provide an understanding of the derivatives of these two concepts.

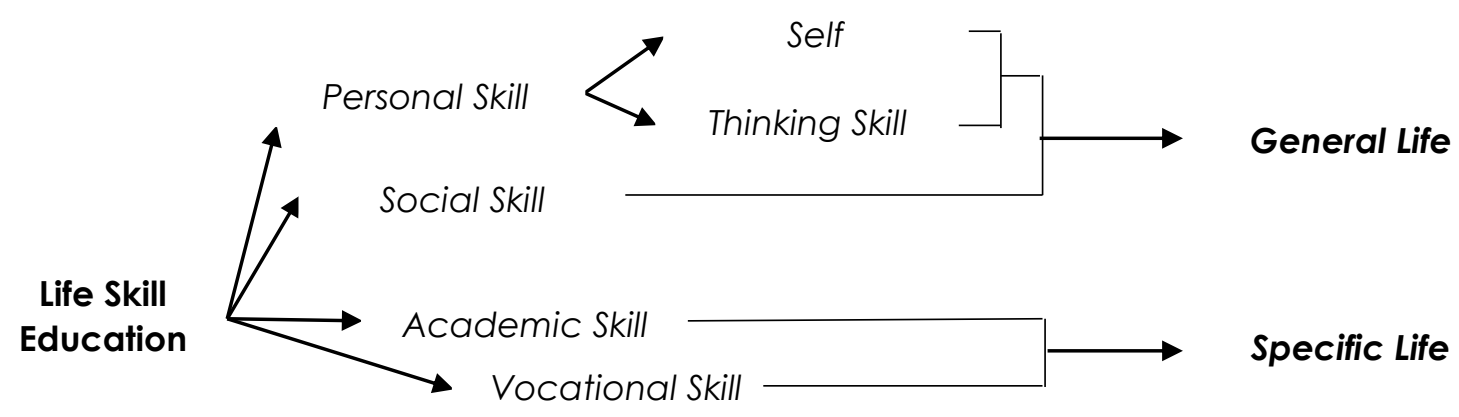

Figure 1. Schematic of Life

If it is understood more deeply, the concept of life skills education is following the four pillars of education in the world proclaimed by UNESCO. As Delors (1996) learning to know, learning to do, learning to be, and learning to live together. The four pillars of world education are implemented in schools to provide students with necessary provisions for life in society. Students should be actively involved in the learning process (interacting with the environment), the learning process becomes a facility for students to practice actions based on their understanding to provide many learning experiences, through this learning experience an educator must be able to strive for confidence-building and personal plurality and ability to interact in groups.

The targets in the life skill education programs developed by PPM MBS Yogyakarta to develop character education already refer to the primary goals in life skills education. The four main components of life skills development targets explain that life skills education is complex targeting all aspects of life, personal and individual performance. In PPM MBS Yogyakarta, the programs that exist every week, month, and year, as well as the daily habituation activities of students, cover the four targets, all students are trained in thinking, feeling, health, and skills in applying with the program of organizing and cultivating Islamic boarding schools. 


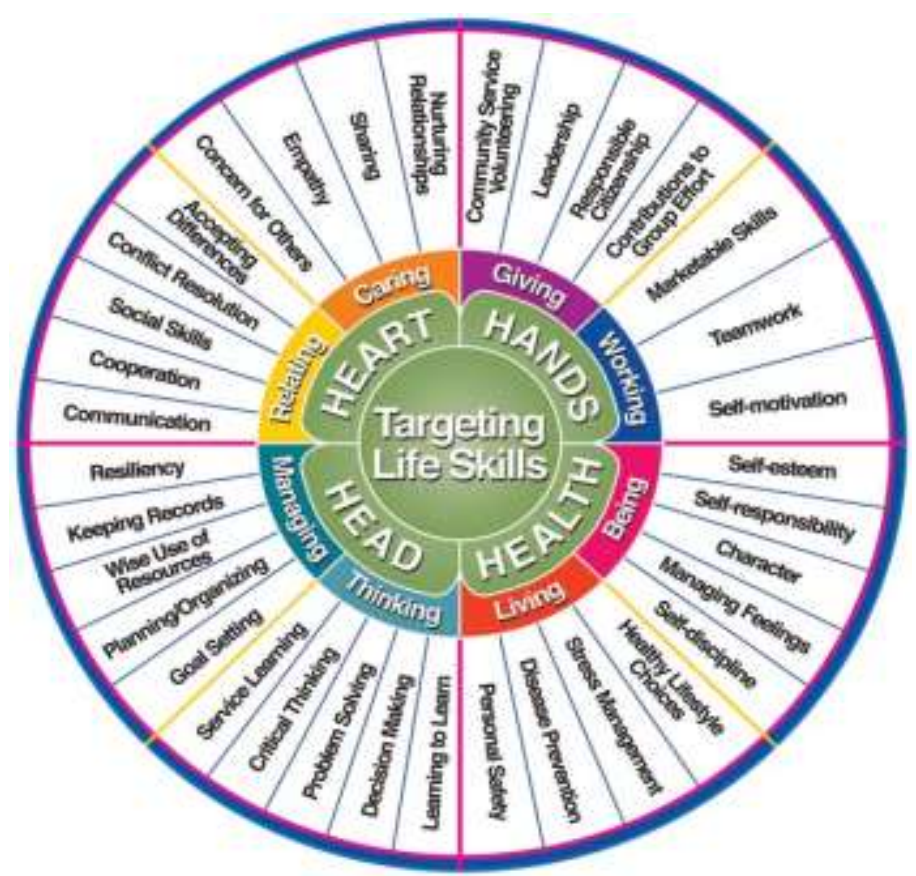

Figure 2. Life Skills Targeting

Hendricks, P. A. Targeting Life Skills. Iowa State University Extension. 1996. Source: Wilson \& McKee (2015)

Another statement by Tom Hill in his book Making Character First "Building a Culture of Character in Any Organization" character influences the way a person thinks and acts. Intrinsic motivation to perform the best behaviour in all situations makes a person have good character. It shows the interconnectivity between life skills education and character education (Rokhman et al., 2014). These life skills education programs merge with the principles of the character education process. Character education intended to develop the value of virtue. They were willing the desired character, clearly related to what is right, caring about what is right, and doing what believed to be right by providing opportunities to practice (Cohen, 2001; Lickona, 1996, 1999, 2003). Lickona (2003) sees character education in three elements; knowledge of morals, feelings about morals, and moral actions. The process of character education through sharing life skill education programs developed by PPM MBS Yogyakarta refers to these three elements, starting with the provision of studies on virtue, followed by a deepening of God's nature based on an almighty deity. As Islamic boarding schools are identical to Islam's religious values, giving recognition of the truth of a moral is strengthened by practice or practice in programs that have developed. Another exciting thing is that the character education process integrated into life skills education requires habituation, namely a daily activity program. Character education cannot teach like the subject matter in general (such as mathematics, science, or/and art) it needs habituation to achieve success (Gunawan, 2012; Kementerian Pendidikan dan Kebudayaan, 2017; Rothman et al., 2014). 
The broad discussion of life skill education programs developed by PPM MBS Yogyakarta as a process in character education follows excellent life skills education and character education. Furthermore, to further see the program's level of effectiveness and efficiency in more detail and depth, the researchers describe it below.

\subsection{Daily Activity Program}

Various activities carried out every day, starting from waking up to going back to sleep. This education model is the same as the national program, namely the full-day school. This educational model is considered capable of positively affecting the character education process and necessary provision for students (Leasa \& Batlolona, 2017; Madjid, 2018; Rokhman et al., 2014). Education throughout the day requires special attention to become the focal point of education (Leasa \& Batlolona, 2017). A teacher both at school and in the dormitory, must be able to behave professionally.

Daily activities controlled by the teacher contribute to the life experience of students. Activities carried out with all existing provisions require students to live in discipline, collaborate, communicate with other individuals. Every individual in the boarding school environment takes a role as a family as well as a community, as the principle of successful learning requires good collaboration between schools, families, and communities (Cummins \& Nash, 2014; Saidek et al., 2016; Ward, 1996) provide the conclusion that the educational process with practice provides maximum results.

\subsection{Weekly Activity Program}

We have conveyed many activities on this weekly program in the results of our research. Involvement in religion has a good effect on improving students' character (Haight et al., 2017b). Students get an excellent opportunity to put the theory they get into practice and do what they believe is right.

The weekly flag ceremony became an activity that evoked a sense of nationalism. It is also a forum to provide motivation, policies to socialize or reject the policies set by schools. Extracurricular programs divided into two types; obligatory and optional. They have a unity of purpose to provide, facilitate, and become a forum for developing interest talents and necessary provision in life-real-life extracurricular experiences in ins, development of survival skills, and independence (Efferi, 2017). Likewise, Tapak Suci emphasizes matters of emotional control, self-defence, and up to building self-confidence. Selected extracurricular activities, a form of life skill education that is common in schools. Providing skills according to students' talents and interests, in practice, this program becomes a student-centred learning model.

\subsection{Monthly Activity Program}

The monthly program activities have integrated motivation, sustainability activities, and character values of cooperation, competition, public speaking. The competition was attended by all students at the boarding school both individually and in groups. Of course, this activity builds motivation (Burguillo, 2010; DiMenichi \& Tricomi, 2015; Franken \& Brown, 1995). It

IJEMI Vol.2, No.1, January 2021, pp. 116 135 
also teaches students to collaborate (Wittchen, Krimmel, Kohler, \& Guido, 2013), life skills to compete according to the XXI century with confidence.

Khutbah Akbar is a continuous Asghar da'wah program. This activity aims to expose students to the broader community, thicken mentally, and dare convey material or statements to various audiences. In the end, leadership is leadership that can influence and build motivation.

\subsection{Annual Activity Program}

Various actualization activities in this annual program. ABAS activities, the da'wah of the students, and the santri camp are places to practice skills, knowledge, and values of the virtues they believe. Direct learning goes into the community, is very important as emotional and social learning (Anderson-Butcher et al., 2018; Chung \& McBride, 2015). Development of a student-centred learning framework. Students directly practice life in a community environment by being able to cooperate, socialize, work, teach, be responsible, and are also required to be able to compile, carry out program evaluations. Another exciting thing is the santri da'wah program, as a form of sustainability of the Hizbul Wathon extracurricular program. Students are required to live independently, and this program indirectly sharpens the sensitivity of students in life.

Performing arts and creativity, facilitating students to show their abilities or skills. This activity is a form of support for all students to develop their talents by participating (Miller \& Gentry, 2010). Also, students who join the committee for this activity provide learning about the management of activity with full cooperation and responsibility.

Finally, skills training activities for students who will graduate provide support services for students' socio-economic responsibility (Nagpaul \& Chen, 2019; Prajapati et al., 2016). This program is to face the industrial era 4.0 by providing training in skills that are useful for students' lives in entrepreneurship, being technicians, and teaching employees. Entrepreneurship activity programs designing by providing sewing, handicrafts, make-up, and culinary supplies. Other skills related to technology through design, audio-video, photographer. Students are also given training related to skills as teachers or preachers.

\subsection{Organizing Program}

Relationship of leadership skills, social interaction, and interaction program. IPM MBS Yogyakarta members in several programs Included as a committee. Conceptualization and planning for youth participation in a significant program in organizational education (Cahill \& Dadvand, 2018). PPM MBS Yogyakarta develops a student organization's concept on an ongoing basis between schools and dormitories as an educational institution with a full day school system. There is no separation between the organizations in schools and dormitories, only providing a smaller organizational decline, meaning that PPM MBS Yogyakarta organizes the decentralized government system into student organizations. As Rondinelli and Cheema 
(1983) define devolved powers and responsibilities of lower bodies, this constitutes decentralization.

The IPM MBS Yogyakarta organization as the parent organization of students in charge of the dormitory, mudhabir, and room level organizations. Each small area organization has the same authority, namely giving the organization command under it and its responsible side above it. Relating to police authority within the scope of the organization, but must be in line with the vision, mission, and objectives of the IPM MBS Yogyakarta.

\subsection{Islamic Boarding School Cultural Actualization Program}

They were integrating character education through culture, into one unique program. Melting character values into students' way of life require continuous repetition so that these values become a habit. It is following the concept of character education formulated by the Kementerian Pendidikan dan Kebudayaan (2017) and Lickona (1996) to approach the character education process with three aspects, namely, first, knowledge related to information on virtue values, second, recognizing the truth of a virtue value, and finally, students practice these values until habituation. Culture shapes the habits of students. The analysis of Varela-Candamio et al. (2018) and Schofield et al. (2015) states that culture (environment) affects the character of students.

Supervision and exemplary enlighten learners in practising the values of virtuesupervision gave for direct control of students. Research results by Basualdo-Delmonico and Spencer (2016) and Van Nijnatten and Noordegraaf (2016) state that supervision is more in line with students' development; parental wars are supervising and encouraging example. The results of other studies state that supervision reduces the possibility of bullying in social, physical, and verbal bullying among students (Cho \& Lee, 2018). Supervision should accompany by an example that provides reflections for students to follow. Research by Oktavia and Safrihady (2016) states that role models are useful in the educational process.

Rewards and punishments become a fence in leading students to be wise. Its enforcement show to all individuals in the boarding school environment. The application of protection has a positive effect (Zheng et al., 2017), and vice versa, ignorance hurts students' character (Ngai et al., 2018; Sohn et al., 2019). Those who make achievements will get rewards, and this policy is to motivate students. Students also given shadows of regulations, regulations await for violators. However, its implementation is necessary, and it anticipated that negative values in the implementation result in students' character defects (Haight et al., 2017a). Parenting that tends to be authoritarian provides students results (Liu \& Merritt, 2018; Turba et al., 2019; Zhai, 2017).

One of the most exciting things is the use of language. Communication interactions at PPM MBS Yogyakarta are required to use three languages; Indonesian, Arabic, and English. The use of other languages that violate the regulations, it is clear that the institution wants its students to meet the demands of globalization in the industrial era 4.0 which requires multi- 
language proficiency, however, on the other hand, there is a need for further study that the prohibition of using regional languages does not heed central or regional government policies. Expressly, In (Undang-Undang Dasar Negara RI Tahun 1945, 2002) article 32 stating the obligation to maintain and develop cultural values, reinforced by (Peraturan Pemerintah Republik Indonesia Nomor 57 Tahun 2014 Tentang Pengembangan, Pembinaan, Dan Pelindungan Bahasa Dan Sastra Serta Peningkatan Fungsi Bahasa Indonesia, 2014; UndangUndang RI Nomor 24 Tahun 2009 Tentang Bendera, Bahasa, Dan Lambang Negara Serta Lagu Kebangsaan, 2009; Undang-Undang Republik Indonesia Nomor 5 Tahun 2017 Tentang Pemajuan Kebudayaan, 2017) contains a policy against language to be directed at three actions namely safeguarding, utilizing, and developing. We think policymakers need to pay attention to preserving the culture of the archipelago as the identity of the nation and the country.

\section{CONCLUSION}

The phenomenon of the rapid development of technology, information, and communication in the twentieth century demands competence and morality. Anxiety will reduce the morale of adolescents, demanding stakeholders to take character education policy steps. The success of character education can achieve with various strategies. Life skills education programs are a part of this strategy. It oriented towards self-development and the culture of the Islamic boarding school. Both are the first steps in children's ancient anticipation.

\section{ACKNOWLEDGMENTS}

We hope that scientific studies on this issue will continue to encourage new directions for the education system in all institutions and places. Thanks also to the ICELI reviewers and editors for assessing this work.

\section{REFERENCES}

Anderson-Butcher, D., Martin, E., Paluta, L., \& Gould, D. (2018). Patterns of social skill development over-time among clusters of LiFEsports participants. Children and Youth Services Review, 87, 17-25. https://doi.org/10.1016/j.childyouth.2018.01.044

Anwar. (2015). Pendidikan Kecakapan Hidup: Life Skills Education. Alfabeta.

Basualdo-Delmonico, A. M., \& Spencer, R. (2016). A parent's place: Parents', mentors' and program staff members' expectations for and experiences of parental involvement in community-based youth mentoring relationships. Children and Youth Services Review, 61, 6-14. https://doi.org/10.1016/j.childyouth.2015.11.021

Burguillo, J. C. (2010). Using Game Theory and Competition-based Learning to Stimulate Student Motivation and Performance. Computers and Education, 55(2), 566-575. 
https://doi.org/10.1016/j.compedu.2010.02.018

Cahill, H., \& Dadvand, B. (2018). Re-conceptualizing youth participation: A framework to inform action. Children and Youth Services Review, 95, 243-253. https://doi.org/10.1016/j.childyouth.2018.11.001

Cho, S., \& Lee, J. M. (2018). Explaining physical, verbal, and social bullying among bullies, bullying victims, and bully-victims: Assessing the integrated approach between social control and lifestyles-routine activities theories. Children and Youth Services Review, 91 , 372-382. https://doi.org/10.1016/j.childyouth.2018.06.018

Chung, S., \& McBride, A. M. (2015). Social And Emotional Learning in Middle School Curricula: A Service Learning Model Based on Positive Youth Development. Children and Youth Services Review, 53, 192-200. https://doi.org/10.1016/j.childyouth.2015.04.008

Cohen, J. (2001). Caring Classrooms/Intelligent Schools: The Social-Emotional Education of Young Children. Teachers College Press.

Cummins, M. M., \& Nash, S. (2014). Urban Youth Develop Life Skills, Raising Livestock. Journal of Extension, 52 (5). https://www.joe.org/joe/2014october/iw7.php

Delors, J. (1996). Learning: the treasure within; report to UNESCO of the International Commission on Education for the Twenty-first Century (Highlights). UNESCO Publishing. https://unesdoc.unesco.org/ark:/48223/pf0000109590

DiMenichi, B. C., \& Tricomi, E. (2015). The power of competition: Effects of social motivation on attention, sustained physical effort and learning. Frontiers in Psychology, 6, 1282. https://doi.org/10.3389/fpsyg.2015.01282

Efferi, A. (2017). Pengembangan Life Skill Siswa Madrasah Melalui Kegiatan Ekstrakurikuler Berkebun. Edukasia: Jurnal Penelitian Pendidikan Islam, 12(1), 189-212. https://doi.org/http://dx.doi.org/10.21043/edukasia.v12i1.2349

Franken, R. E., \& Brown, D. J. (1995). Why do people like competition? The motivation for winning, putting forth the effort, improving one's performance, performing well, being instrumental, and expressing forceful/aggressive behavior. Personality and Individual Differences, 19(2), 175-184. https://doi.org/10.1016/0191-8869(95)00035-5

Gunawan, H. (2012). Pendidikan Karakter: Konsep dan Implementasi. Alfabeta.

Haight, W., Sugrue, E., Calhoun, M., \& Black, J. (2017a). "Basically, I look at it like combat": Reflections on moral injury by parents involved with child protection services. Children and Youth Services Review, 82, 477-489. https://doi.org/10.1016/j.childyouth.2017.10.009

Haight, W., Sugrue, E., Calhoun, M., \& Black, J. (2017b). Everyday coping with moral injury: The perspectives of professionals and parents involved with child protection services. Children and Youth Services Review, 82, 108-121. https://doi.org/https://doi.org/10.1016/j.childyouth.2017.09.025

Handono, S. G., Laeheem, K., \& Sittichai, R. (2019). Factors related with cyberbullying among the youth of Jakarta, Indonesia. Children and Youth Services Review, 99, 235-239. 
https://doi.org/10.1016/j.childyouth.2019.02.012

Hasbullah. (2012). Dasar-Dasar Ilmu Pnedidikan. Rajawali Pers.

Iskandar, W., \& Narimo, S. (2017). Pengelolaan Full Day School dalam Membentuk Karakter Siswa SD. Jurnal Managemen Pendidikan, 13(1), 24-33. https://doi.org/https://doi.org/10.23917/jmp.v13i2.6393

Julistiaty, R, M., \& Matin. (2018). Manajemen Pendidikan dalam Membentuk Karakter Siswa SMP Tunas Bangsa Sunter. Chinese Journal of Sensors and Actuators, 6(2), 241-251. https://doi.org/https://doi.org/10.21831/amp.v6i2.20618

Kementerian Pendidikan dan Kebudayaan. (2017). Konsep dan Pedoman Penguatan Pendidikan Karakter: Tingkat Sekolah Dasar dan Sekolah Menengah Pertama. Kementerian Pendidikan dan Kebudayaan.

KPAI. (2017). Data Kasus Pertahun/Rincian Data Kasus Berdasarkan Klaster Perlindungan Anak 2011-2016. BANK DATA Perlindungan Anak. http://bankdata.kpai.go.id/tabulasidata/data-kasus-per-tahun/rincian-data-kasus-berdasarkan-klaster-perlindungananak-2011-2016

KPAI. (2018). KPAI Sebut Anak Korban Kejahatan Dunia Maya Capai 679 Kasus. KPAI (Komisi Perlindungan Anak Indonesia. https://www.kpai.go.id/berita/kpai-sebut-anak-korbankejahatan-dunia-maya-capai-679-kasus

Leasa, M., \& Batlolona, J. R. (2017). Full Day School dalam Pembentukan Karakter Siswa SMK Negeri 13 Kota Malang. Jurnal Ilmu Sosial Dan Humaniora, 6(1), 73. https://doi.org/10.23887/jish-undiksha.v6il.9903

Lickona, T. (1996). Eleven Principles of Effective Character Education. Journal of Moral Education, 25(1), 93-100. https://doi.org/10.1080/0305724960250110

Lickona, T. (1999). Character Education: Seven Crucial Issues. Action in Teacher Education, 20(4), 77-84. https://doi.org/10.1080/01626620.1999.10462937

Lickona, T. (2003). My Thought About Character. Comell University Press.

Liu, Y., \& Merritt, D. H. (2018). Examining the association between parenting and childhood depression among Chinese children and adolescents: A systematic literature review. Children and Youth Services Review, 88, 316-332. https://doi.org/https://doi.org/10.1016/j.childyouth.2018.03.019

Madjid, A. (2018). Full-Day School Policy For Children's Character Development: Lessons from Indonesian Islamic Education. The Online Journal of New Horizons in Education, 8(3), 5160.

Miles, M. B., Huberman, A. M., \& Saldana, J. (2014). Qualitative Data Analysis: A Methods Sourcebook (T. R. Rohidi (ed.); Edition 3). Sage Publications : UI-Press.

Miller, R., \& Gentry, M. (2010). Developing Talents Among High-Potential Students From LowIncome Families in an Out-of-School Enrichment Program. Journal of Advanced Academics, 21 (4), 594-627. https://doi.org/https://doi.org/10.1177/1932202X1002100403 
Nagpaul, T., \& Chen, J. (2019). Self-determination theory as a Framework for understanding youth-at-risk needs: Perspectives of social service professionals and the youth themselves. Children and Youth Services Review, 99, 328-342. https://doi.org/10.1016/j.childyouth.2019.02.015

Ngai, S. S., Xie, L., Ng, Y., \& Ngai, H. (2018). The effects of parenting behavior on prosocial behavior of Chinese adolescents in Hong Kong. Children and Youth Services Review, 87, 154-162. https://doi.org/10.1016/j.childyouth.2018.02.030

Nucci, L., Narvaez, D., \& Krettenauer, T. (2014). Handbook of moral and character education. In Handbook of Moral and Character Education. https://doi.org/10.4324/97802031 14896 Nugroho, R. (2008). Pendidikan Indonesia: Harapan, Visi, dan Strategi. Pustaka Pelajar.

Oktavia, W., \& Safrihady, S. (2016). Teacher Role in Formation Politeness of Student Learning Process. JETL (Journal Of Education, Teaching and Learning), 1(2), 95. https://doi.org/10.26737/jetl.v1i2.46

Peraturan Menteri Pendidikan dan Kebudayaan RI Nomor 20 Tahun 2018 tentang Penguatan Pendidikan Karakter Pada Satuan Pendidikan Formal, (2018).

Peraturan Pemerintah Republik Indonesia Nomor 57 Tahun 2014 tentang Pengembangan, Pembinaan, dan Pelindungan Bahasa dan Sastra Serta Peningkatan Fungsi Bahasa Indonesia, (2014). https://peraturan.bpk.go.id/Home/Details/5497

Peraturan Presiden RI Nomor 87 Tahun 2017 tentang Penguatan Pendidikan Karakter, (2017). https://setkab.go.id/inilah-materi-perpres-no-87-tahun-2017-tentang-penguatanpendidikan-karakter/

Prajapati, R., Sharma, B., \& Sharma, D. (2016). Significance Of Life Skills Education. Contemporary Issues in Education Research (CIER), 10(1), 1-6. https://doi.org/10.19030/cier.v10i1.9875

Rokhman, F., Hum, M., Syaifudin, A., \& Yulianti. (2014). Character Education for Golden Generation 2045 (National Character Building for Indonesian Golden Years). Procedia Social and Behavioral Sciences, 141, 1161-1165. https://doi.org/10.1016/j.sbspro.2014.05.197

Rondinelli, D. A., \& Cheema, G. S. (1983). Decentralization and development: policy implementation in developing countries. Hills.

Saidek, A. R., Islami, R., \& Abdoludin. (2016). Character Issues: Reality Character Problems and Solutions through Education in Indonesia. Journal of Education and Practice, 7(17), 158165.

Schofield, G., Biggart, L., Ward, E., \& Larsson, B. (2015). Looked after children and offending: An exploration of risk, resilience and the role of social cognition. Children and Youth Services Review, 51, 125-133. https://doi.org/10.1016/j.childyouth.2015.01.024

Sohn, B., Buchanan, A., Heo, K. H., \& Lee, J. J. (2019). Explanatory effects of young childhood caregiving environment, child's pro-social behavior, and child self-regulation skills on 
adolescent problem behavior. Children and Youth Services Review, 100, 298-303. https://doi.org/10.1016/j.childyouth.2019.03.016

Suhardan, D. (2012). Ekonomi dan Pembiayaan Pendidikan. Alfabeta.

Tim Broad Based Education. (2002a). Konsep Pendidikan Kecakapan Hidup (Life Skills Education) BUKU I. Depdiknas.

Tim Broad Based Education. (2002b). Pola Pelaksanaan Broad Based Education (Life Skill Education) BUKU II. Depdiknas.

Tomczyk, Ł. (2017). Cyberbullying in 2010 and 2015 - A perspective on the changes in the phenomenon among adolescents in Poland in the context of preventive action. Children and Youth Services Review, 75, 50-60. https://doi.org/10.1016/j.childyouth.2017.02.017

Turba, H., Breimo, J. P., \& Lo, C. (2019). Professional and organizational power intertwined: Barriers to networking? Children and Youth Services Review, 107, 104527. https://doi.org/10.1016/j.childyouth.2019.104527

Tyler Wilson, \& McKee, R. K. (2015). Impact 4-H Makes. Purdue Extension. https://extension.purdue.edu/4h/Pages/impact.aspx

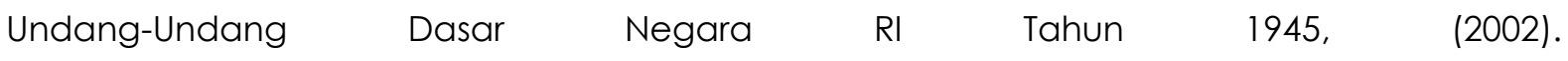

https://mkri.id/index.php?page=web.PeraturanPIH\&id=1 \&menu=6\&status=1

Undang-Undang RI Nomor 24 Tahun 2009 tentang Bendera, Bahasa, dan Lambang Negara Serta Lagu Kebangsaan, (2009). https://peraturan.bpk.go.id/Home/Details/38661/uUno-24-tahun-2009

Undang-Undang Republik Indoonesia Nomor 5 Tahun 2017 tentang Pemajuan Kebudayaan, (2017). https://peraturan.bpk.go.id/Home/Details/37642/uu-no-5-tahun-2017

UNDP, (United Nations Development Programme). (2018). Human Development Indices and Indicators 2018 Statistical Update. In the United Nations Development Programme: Human Development Report. http://hdr.undp.org/en/2018-update

Utami, A. N., Hernawati, N., \& Alfiasari. (2016). Pengasuhan Orang Tua yang Seimbang Sebagai Kunci Penting Pembentukan Karakter Remaja. Jurnal Pendidikan Karakter, VI(1), 1-15. https://doi.org/https://doi.org/10.21831/jpk.v0i1.10727

Van Nijnatten, C., \& Noordegraaf, M. (2016). Constructing familyness: Pedagogical conversations between professional parents and adolescents. Children and Youth Services Review, 61, 296-302. https://doi.org/10.1016/j.childyouth.2015.11.028

Varela-Candamio, L., Novo-Corti, I., \& Garcia-Alvarez, M. T. (2018). The importance of environmental education in the determinants of green behavior: A meta-analysis approach. Journal of Cleaner Production, 170, 1565-1578. https://doi.org/10.1016/j.jclepro.2017.09.214

Ward, C. K. (1996). Life Skill Development Related to Participation in 4-H Animal Science Projects. Journal of Extension, 2(34). https://www.joe.org/joe/1996april/rb2.php 
Zhai, F. (2017). Cultural orientation, parental nurturance, and parent-child conflict among Asian American parents in New York City. Children and Youth Services Review, 76, 1-9. https://doi.org/10.1016/j.childyouth.2017.02.026

Zheng, L., Li, X., \& Huang, R. (2017). The Effect of Socially Shared Regulation Approach on Learning Performance in Computer-Supported Collaborative Learning. Journal of Educational Technology \& Society, 20(4), 35-46. http://www.jstor.org/stable/26229203 